\title{
Coronavirus replication and pathogenesis: Implications for the recent outbreak of severe acute respiratory syndrome (SARS), and the challenge for vaccine development
}

\author{
Sonia Navas-Martín and Susan R Weiss \\ Department of Microbiology, University of Pennsylvania, School of Medicine, Philadelphia, Pennsylvania, USA
}

\begin{abstract}
A novel coronavirus has been recently identified as the causative agent of the severe acute respiratory syndrome (SARS) outbreak that has accounted for more than 8000 infected people worldwide. This review will discuss current knowledge on coronavirus replication, pathogenesis, evolution, and vaccine strategies, as well as the most recent findings on SARS coronavirus. Journal of NeuroVirology (2004) 10, 75-85.
\end{abstract}

Keywords: coronavirus mutation; replication; SARS; vaccine

\section{Coronaviruses and the outbreak of SARS}

Coronaviruses comprise a large group of enveloped, positive-sense, single-stranded polyadenylated RNA viruses classified in the Nidovirales order (Gonzalez et al, 2003; Siddell, 1995). Coronaviruses have the largest viral RNA genomes known (ranging from 27.6 to $31.6 \mathrm{~kb}$ ). Coronaviruses are classified into three groups (I to III) based on serological cross-reactivity (Enjuanes, 2000) (Table 1). Recently, phylogenetic analysis studies have supported the existence of these three groups (Gonzalez et al, 2003). Group I coronaviruses include important animal pathogens, such as the porcine transmissible gastroenteritis virus (TGEV), porcine epidemic diarrhea virus (PEDV), and feline infectious peritonitis virus (FIPV). Group II also includes pathogens of veterinary relevance, such as the bovine coronavirus (BCoV), porcine hemagglutinating encephalomyelitis virus (HEV), and equine coronavirus (ECoV). Murine hepatitis virus (MHV) and rat coronavirus (RtCoV) also belong to group II.

Address correspondence to Dr. Susan R. Weiss, Department of Microbiology, University of Pennsylvania, School of Medicine, 36th Street and Hamilton Walk, Philadelphia, PA 19104-6076, USA. E-mail: weisssr@mail.med.upenn.edu

The authors are indebted to many colleagues for helpful discussions and thoughts. We acknowledge NIH grants AI17418, NS21954, NS30606, and AI47800, as well as RG2585B5 from the National Multiple Sclerosis Society.

Received 8 December 2003; accepted 10 December 2003.
Group III coronaviruses infect avian species, and at the present time only three viruses have been assigned to this group, infectious bronchitis virus (IBV), turkey coronavirus (TCoV), and pheasant coronavirus (Cavanagh et al, 2002). Human coronaviruses belongs to groups I (HCoV-229E) and II (HCoV-OC43) (discussed below).

Coronaviruses can now be considered as emerging pathogens. Although the first cases of "an atypical pneuomonia" appear to have originated in Guangdong Providence (China) in late 2002 (Parry, 2003), it was not until February 2003 that the World Health Organization (WHO) received reports from China of an outbreak with more than 300 cases and 5 deaths in Guangdong Providence (WHO, 2003). Late in February 2003, the epidemic spread from Guangdong to a hotel in Hong Kong by a doctor from Guangdong Providence who was treating atypical pneumonia patients (Lee et al, 2003). The epidemic appears to have spread from this hotel in Hong Kong to Hanoi by an Chinese-American business man who had been in that hotel. By then, Dr. Carlo Urbani, who was a WHO officer based in Hanoi, was the first to identify the symptoms of this atypical pneumonia with a new respiratory illness, which he called "severe acute respiratory syndrome" (SARS). Dr. Urbani died on March 29 in Bangkok with symptoms of the new disease (Reilley et al, 2003). By late March, SARS had spread to many locations, mostly in Asia, but also to Toronto, Canada (Poutanen et al, 2003). A novel virus was isolated from patients' lungs and sputum 
Table 1 Coronavirus groups, host tropism, receptors, and diseases

\begin{tabular}{lclll}
\hline Host & Group & Virus & Receptor & Co-Receptor $^{a}$ \\
\hline Cat & 1 & FIPV & Feline APN & R, E, S \\
Cat & 1 & FCoV & Feline APN & E \\
Dog & 1 & CCoV & Canine APN & R, E \\
Pig & 1 & TGEV & Porcine APN & (R) E \\
Pig & 1 & PRCoV & Porcine APN & R \\
Pig & 1 & PEDV & Porcine APN & E \\
Human & 1 & HCoV-229E & ACE2 APN & R \\
Human & $?$ & SARS-CoV & $?$ & R, E \\
Human & 2 & HCoV-OC43 & mCEACAM1 & R \\
Mouse & 2 & MHV & (R) E, CNS \\
Rat & 2 & RCoV & $?$ & R \\
Pig & 2 & HEV & 9-0AcNA & E \\
Cattle & 2 & BCoV & $?$ & R-0AcNA \\
Chicken & 3 & IBV & $?$ & R, E \\
Turkey & 3 & TCoV & $?$ & R, E \\
Pheaasant & 3 & PHCoV & R nephritis \\
\hline
\end{tabular}

${ }^{a} \mathrm{HCoV}-\mathrm{OC} 43$ and HCoV-OC229 cause the $30 \%$ of common colds in humans; SARS-CoV, severe acute respiratory syndrome; FIPV, feline infectious peritonitis virus; FCoV, feline enteric coronavirus; CCV, canine coronavirus; TGEV, porcine transmissible gastroenteritis virus; PEDV, porcine epidemic diarrhea virus; MHV, mouse hepatitis virus; RCoV, rat coronavirus; HEV, porcine hemagglutinating encephalomyelitis virus; BCoV, bovine coronavirus; IBV, infectious bronchitis virus; TCV, turkey coronavirus; PHCoV, pheasant coronavirus. ${ }^{\mathrm{b}} \mathrm{R}$, respiratory; E, enteric; S, systemic; CNS, central nervous system.

and cultivated in a monkey kidney cell line (Vero E6) (Drosten et al, 2003a, 2003b; Ksiazek et al, 2003; Peiris et al, 2003b). The SARS epidemic was officially controlled by July 2003 (Ashraf, 2003; Fleck, 2003). Strikingly, the epidemic was controlled by isolation only. The worldwide SARS epidemic has accounted for more than 8000 infected people worldwide and more than 800 deaths, with mortality rates that vary and are somewhat dependent on age ( $5 \%$ to $43 \%$ ) (Donnelly et al, 2003).

SARS infection exhibits a wide clinical course, mainly characterized by fever, dyspnea, lymphopenia, and lower tract respiratory infection (Nie et al, 2003; Tsui et al, 2003). Concurrent gastrointestinal symptoms and diarrhea have also been reported (Booth et al, 2003; Lee et al, 2003; Leung et al, 2003; Peiris et al, 2003a). Although the route of transmission has not been clearly established, airborne droplets from infected patients may be the main route of transmission (Zhong et al, 2003). However, blood transmission and fecal-oral transmission cannot be rule out. Strikingly, it has been recently reported that the SARS coronavirus (SARS-CoV) replicates in peripheral blood mononuclear cells (PBMCs) from SARS patients (Li et al, 2003a). Furthermore, active replication of SARS-CoV in both the small and large intestine has been recently demonstrated. In addition, SARS-CoV was detected in the stools of the patients for more than 10 weeks after symptom onset (Leung et al, 2003).

The mechanism of injury caused by SARS-CoV infection remains unknown. A SARS disease model has been proposed, consisting of three phases: viral replication, immune hyperactivity, and pulmonary destruction (Tsui et al, 2003). SARS pathology of the lung has been associated with diffuse alveolar damage, epithelial cell proliferation, and an increase of macrophages. Multinucleate giant-cell infiltrates of macrophage or epithelial origin have been associated with putative syncytium-like formation that is characteristic of many coronavirus infections (Nicholls et al, 2003). Lymphopenia, hemophagocytosis in the lung, and white-pulp atrophy of the spleen observed in SARS patients are reminiscent of that reported in fatal influenza subtype H5N1 disease in 1997 (To et al, 2001). Strikingly, the presence of hemophagocytosis supports a cytokine dysregulation (Fisman, 2000). Proinflammatory cytokines released by stimulated macrophages in the alveoli may have a role in the pathogenesis of SARS. Based on this cytokine deregulation hypothesis, treatment of SARSinfected patients has included the administration of steroids, aimed to modulate the exacerbated cytokine response, similarly to the treatment of nonviral acute respiratory distress syndrome (Lai et al, 2003). However, treatments of SARS infection have been ineffective (Koren et al, 2003; Lee et al, 2003; Tsui et al, 2003). Treatment have been based in the administration of antibacterials (to prevent secondary bacterial infections) and steroids (methylprednisolone, or corticosteroids, to modulate cytokine dysregulation) in combination with ribavirin, a nucleoside analog with broad antiviral activity that is being used for the treatment of respiratory syncytial virus (RSV) infection (Everard et al, 2001) and for the management of hepatitis C infection (Lipman and Cotler, 2003; Martin et al, 1998). At the present, the lack of ribavirin response is not understood. We have recently proposed a possible mechanism for the natural resistance of SARS-CoV to ribavirin based on a molecular model of SARS-CoV polymerase (Xu et al, 2003). We propose that the clinically observed resistance of SARS to ribavirin is probably due to perturbation of a conserved motif A that controls rNTP binding and fidelity 
of polymerization (Xu et al, 2003). Recently, the antiviral potential of interferons (IFNs) $\alpha, \beta$, and $\gamma$ has been assessed in Vero and Caco2 cell cultures, IFN $\beta$ being the most potent inhibitor of SARS-CoV (Cinatl et al, 2003).

Coronaviruses induce acute self-limited as well as chronic persistent infections, and cause a wide range of pathologies, such as acute respiratory disease, encephalitis, chronic demyelination in the central nervous system (CNS), hepatitis, and enteritis (Holmes, 1996). In general, coronaviruses infect the respiratory and enteric mucosal surfaces, although macrophages, hepatocytes, endothelial cells, neurons, oligodendrocytes, and astrocytes are main target cells for some coronaviruses, such as MHV (Haring and Perlman, 2001; Navas-Martín and Weiss, 2003). Some coronaviruses have an important impact on farm animals, i.e., porcine (TGEV), avian (IBV), and bovine (BCoV) coronaviruses causes respiratory and enteric infections that account for severe economic loss (Holmes, 1996). In addition, coronaviruses are also being studied as animal models for viral pathogenesis. For example, some strains of murine coronavirus (MHV) cause encephalitis and chronic demyelination in experimentally infected mice, thus MHV infection of the mouse is used as an animal model for human CNS demyelinating diseases such as multiple sclerosis (Buchmeier and Lane, 1999; Haring and Perlman, 2001).

Before the discovery of a previously unknown coronavirus as the causative agent of the SARS, two coronaviruses were known to infect humans, causing self-limiting upper respiratory tract infections (Myint, 1994). These human coronaviruses, HCoV$229 \mathrm{E}$ and HCoV-OC43, cause about the $30 \%$ of the common colds and have never been reported to cause severe illness. However, human coronaviruses have been reported to be associated with multiple sclerosis, although this has never been confirmed (Talbot, 1995). So far, the more direct evidence that could suggest a neurotropic potential is the fact that both HCoV-229E and HCoV-OC43 can infect primary cultures of human neural cells, in particular fetal astrocytes (Bonavia et al, 1997). Strikingly, SARS-CoV has been detected by real-time polymerase chain reaction (PCR) in the cerebrospinal fluid of a patient with SARS, who also showed an epilepticus status (Hung et al, 2003). The significance of this finding is limited because no other association with CNS symptoms in SARS-infected patients have been reported so far.

Although the origin of the SARS-CoV remains unknown, phylogenetic analysis has demonstrated that SARS-CoV belongs to the Coronaviridae family (Marra et al, 2003; Rota et al, 2003). SARS-CoV genome organization shares some hallmarks of other coronavirus genomes, although some characteristics are unique to SARS-CoV (Figure 1). For example, unlike group II coronaviruses, SARS has no hemagglutinin (HA) esterase (HE) gene, a gene homologous to the HA from influenza $C$ virus (Luytjes et al, 1988).

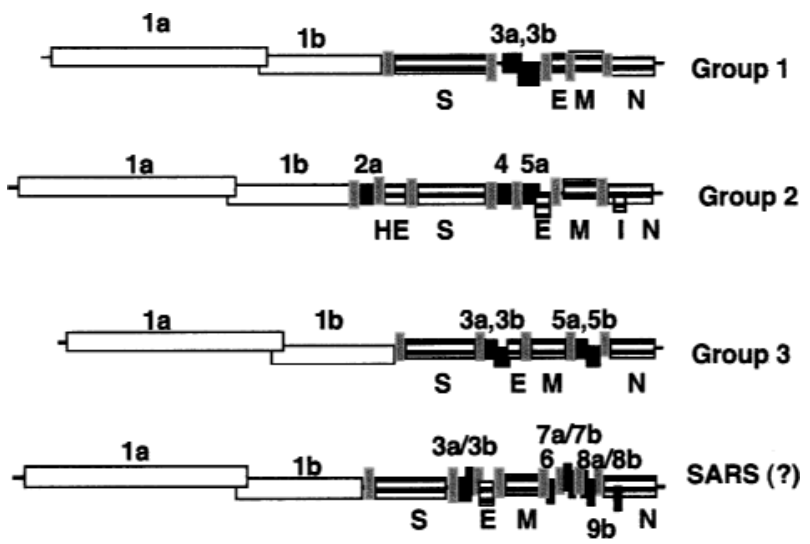

Figure 1 Coronavirus genomes representing three antigenic groups. SARS-CoV has been suggested to define either a new coronavirus group (4), an early spilt-off from group 2 , and a recombinant virus (discussed in the text). Genome organization of coronavirus groups 1, 2, and 3 are shown along with the SARS-CoV genome. The replicase gene (ORFs 1a, $1 \mathrm{~b}$ ) is shown by open bars; structural genes (S, E, M, N, and HE) are depicted with striped bars; nonstructural genes (black bars) are variable in number and location in the coronavirus genome among the different viral groups. Small open reading frames (ORFs) are depicted in solid bars.

Like group I coronaviruses, SARS-CoV spike protein lacks a cleavage recognition site. Like group III coronaviruses, SARS-CoV has only one papain-like protease (plp-2) encoded in open reading frame 1a. Similar to group III, at the $3^{\prime}$ UTR region of SARS, there is a conserved sequence motif that is though to have been acquired from astroviruses (Jonassen et al, 1998). Early after its discovery, SARS-CoV was suggested to define a new group (IV) within the coronavirus genus (Ksiazek et al, 2003; Marra et al, 2003; Rota et al, 2003). However, other report has suggested that it is more directly related to group II coronaviruses, along with the bovine coronavirus, the human OC43 virus, and the murine coronavirus (MHV) (Snijder et al, 2003). Rest et al have recently suggested that the SARS-CoV polymerase may be a result of recombination (Rest and Mindell, 2003). Based on this rooted analysis using Bayesian inference (Huelsenbeck et al, 2001), the $5^{\prime}$ RNAdependent RNA polymerase (RDRP) fragment diverges from others coronaviruses prior to divergences between and within groups I to III, whereas there is a sister relationship between the more recently diverged SARS-CoV $3^{\prime}$ RDRP polymerase fragment and group 3 avian coronaviruses (Rest and Mindell, 2003). It is worth noting, however, that these authors have used Bayesian inference and amino acid sequences rather than nucleotides in their phylogenetic analysis.

The molecular determinants that may account for the dramatic differences in pathogenesis between the human coronaviruses (HCoV-229E, HCoV-OC43) and SARS-CoV are currently unknown and are almost certainly multigenic. Although coronaviruses infect a broad range of animals, including humans, other 
mammals, and birds, it has been accepted that each individual virus has very restricted host range. This is based on the observations that, thus far, the ability of coronaviruses to replicate in a particular cell type depends solely on the ability to interact with their receptors (Holmes, 1996). For example, murine coronavirus replicates in murine cells, and not in hamster, human, monkey, or cat cells; however, once the nonpermissive cells are transfected with the cDNA encoding MHV receptor, carcinoembryonic antigen-cell adhesion molecule 1 (CEACAM1), they become susceptible to MHV infection (Dveksler et al, 1996). This narrow host range is determined by the specific interaction between the spike (S) protein of coronaviruses (present in the viral envelope) and their respective receptor in the cellular membrane. Until now, coronaviruses have been poorly studied from the structural biology standpoint, perhaps mainly due to their lack of clinical relevance. Strikingly, there is no structural data on coronavirus spikes. Although some coronavirus receptors have been identified, the lack of structural data for coronavirus spikes has hampered the study of coronavirus entry. Group I coronaviruses, such as human HCoV-229E, use aminopeptidase N (APN; CD13), a zinc-binding protease, of their normal host species as their receptors (Yeager et al, 1992) (Table 1). Human aminopeptidase $\mathrm{N}$ is found on the cell surface of apical membranes of intestinal, lung, kidney, and epithelial cells, macrophages, and synaptic junctions (Kunz et al, 1994; Look et al, 1989). Interestingly, HCoV-229E can utilize either human APN or feline APN as a receptor, but cannot use porcine APN (Wentworth and Holmes, 2001a, $2001 \mathrm{~b})$. Among group II coronaviruses, only the receptor for the murine coronavirus (MHV) is known. MHV enter the cell after binding members of the pleiotropic family of carcinoembryonic antigen-cell adhesion molecules (CEACAMs; CD66a) (Chen et al, 1995, 1997; Dveksler et al, 1993; Nedellec et al, 1994). CEACAMs are glycoproteins possessing two or four immunoglobulin-like extracellular domains followed by a transmembrane domain and a cytoplasmic tail (Nedellec et al, 1994). CEACAMs are involved in the intercellular adhesion and the development of hepatocellular, colorectal, and epithelial tumors (Beauchemin et al, 1999), and are expressed primarily on the epithelial and endothelial cells of the respiratory tract, intestines, and other tissues (Godfraind et al, 1995; Robitaille et al, 1999). Interestingly, they are not well expressed in the brain, a major site of MHV infection. The receptors for the other members of group II coronaviruses remain unknown, although it is known they can use 9-Oacetylated sialic acids as coreceptor (through binding to the HE glycoprotein present in the viral envelope of group II coronaviruses (Holmes, 1996). Strikingly, angiotensin-converting enzyme 2 (ACE2) has been recently identified as a functional receptor for SARS$\mathrm{CoV}$ (Li et al, 2003b). ACE2 is like APN, a zinc metalloprotease.
Coronavirus biological vectors are not known. However, it has been speculated that SARS-CoV has "jumped" from an animal to humans (Holmes, 2003). It is suspected that SARS-CoV has a reservoir in a wild animal species (Holmes, 2003). A range of domestic and wild mammals in Guangdong Province have been examined in order to identify animals carrying SARS-CoV. Interestingly, SARS-like viruses were isolated from live small, wild mammals (Himalayan palm civets, raccoon dogs, and Chinese ferret badgers) in a retail market in China (Guan et al, 2003). Recent data indicate that ferrets and domestic cats are susceptible to SARS-CoV infection and that they can transmit the virus to previously uninfected animals that are housed with them (Martina et al, 2003).

\section{Coronavirus replication}

Coronavirus RNA synthesis occurs in the cytoplasm via a negative-strand RNA intermediate (Holmes, 1996). The virion RNA is infectious and functions as an mRNA, having a $5^{\prime}$ terminal cap followed by a leader sequence and an untranslated region. At the $3^{\prime}$ end of the genome, there is an untranslated region followed by a poly (A) tail. Coronaviruses have a polycistronic genome organization and synthesize multiple subgenomic mRNAs, all overlapping at the $3^{\prime}$ end (nested set of subgenomic RNAs) and all containing the same $5^{\prime}$ leader sequence derived from the $5^{\prime}$ end of the genome. Each mRNA is translated to generate the protein product of its most $5^{\prime}$ gene, but sometimes is translated into a second, downstream protein as well (Fischer et al, 1997). Coronaviruses replicate by a unique discontinous transcription mechanism that is not completely understood. Discontinuous transcription of subgenomic mRNAs is believed to be regulated by transcription regulating sequences (TRSs, also referred to as intergenic sequence) at the $5^{\prime}$ end of each transcriptional unit (La Monica et al, 1992). The current model is that discontinuous transcription occurs during the synthesis of subgenomic negative-sense RNAs; this model is supported by data that demonstrate the existence of transcriptionally active, subgenomic-size negative RNA strands containing the antileader sequence (Snijder et al, 2003).

Coronavirus genes are arranged in the order $5^{\prime}$ replicase-(HE)-S-E-M-N-3', with some other genes that have been found not essential both in vivo and in vitro (de Haan et al, 2002a, 2002b, 2003; Holmes, 1996). The virion envelope surrounding the nucleocapsid contains the following structural proteins: $\mathrm{S}$ (spike), $\mathrm{M}$ (matrix), $\mathrm{E}$ (envelope), and, in the case of group II coronaviruses, HE (hemagglutininesterase). S protein is a $180-\mathrm{kDa}$ peplomer glycoprotein found on the virion envelope and on the plasma membrane of infected cells; S contains epitopes for viral neutralization and T-cell response, and 
is responsible for attachment to the cellular receptor and for both virus-cell fusion during viral entry, and cell-to-cell fusion for some coronaviruses later during infection (Gallagher, 2001). The spike gene contains determinants of tropism and pathogenesis (Navas-Martín and Weiss, 2003). M (matrix) protein is a transmembrane glycoprotein with its carboxy terminus integrated within the virion core; $\mathrm{M}$ is believed to play a key role in maintaining the core structure (Escors et al, 2001). E (envelope) is a 9.6-kDa polypeptide membrane associated protein that is critical for virion assembly (Vennema et al, 1996; Yu et al, 1994) . N, a 60-kDa phosphoprotein complexed with the RNA genome to form the nucleocapsid, forms the virion core or nucleocapsid (Baric et al, 1988). New virions are assembled by budding into intracellular membranes and are released from the cells through vesicles of the secretory pathway (Holmes, 1996; Prentice and Denison, 2001). The role of coronavirus structural proteins in pathogenesis has been reviewed elsewhere (Navas-Martín and Weiss, 2003).

\section{Coronavirus evolution}

Two major forces drive coronavirus evolution: recombination and mutation. Coronaviruses undergo homologous RNA recombination at high frequencies, although the mechanism is not well understood. Signals for RNA polymerase recognition may play a role in coronavirus recombination. Strikingly, recombination has been reported only among coronaviruses of the same group, although intergroup recombination is theoretically possible. For example, intragroup recombination between the feline and canine enteric coronaviruses (Herrewegh et al, 1998), between MHV strains (Keck et al, 1988a, 1988b), and between strains of IBV (Jia et al, 1995; Kottier et al, 1995a, 1995b), has been reported. Recombination events among coronaviruses probably results from a polymerase-jumping mechanism during coinfection (Brian and Spaan, 1997; Lai, 1992). Recombination between animal (bovine coronavirus) and human coronaviruses (HCoV-OC43) in cell culture has been recently reported (Wu et al, 2003). A high potential for recombination among members of group II coronaviruses has been suggested (Wu et al, 2003). Strikingly, Rest et al have found evidence of a recombination breakpoint within the polymerase of SARS-CoV (Rest and Mindell, 2003).

It is well known that RNA viruses mutate at rates in the range of $10^{-3}$ to $10^{-5}$ base substitutions per nucleotide copied (Domingo and Holland, 1997; Domingo et al, 1997; Holland and Domingo, 1998). These values are several orders of magnitude larger than those encountered during replication of DNA viruses, and many orders of magnitude grater than of cellular DNA (Drake, 1991). As a consequence of this high mutation rates, RNA viruses exits as diverse populations composed of ensembles of closely related, nonidentical genomes that are known as viral quasispecies (Domingo et al, 2001). The molecular basis of this complexity is the limited copying fidelity exhibited by the viral replicases (Steinhauer et al, 1992).

Evolution of coronavirus during persistent infection has been investigated using murine coronaviruses, both in vitro and in vivo (Adami et al, 1995; Fleming et al, 1993, 1995; Rowe et al, 1997a, 1997b, 1998; Steinhauer et al, 1992). Murine coronaviruses comprise several pathogenic strains historically known as mouse hepatitis virus (MHV), although only a few are primarily hepatotropic (Haring and Perlman, 2001; Navas-Martín and Weiss, 2003). MHV causes both persistent and acute self-limited infections (Haring and Perlman, 2001). MHV naturally infects mice via the respiratory and enteric routes. However, in laboratory strains, the outcome of MHV infection is dependent upon the route and dose of inoculation, and host factors such as age, genetic background, immune status, and virus strain (some are neurotropic, some are hepatotropic, and others exhibits both tropisms) (Siddell, 1995). Although the virus is cleared, viral RNA may persist in the CNS for more that 1 year after infection (Fleming et al, 1995). MHV recombinants arise during passage in tissue culture as well as in inoculated mice (Rowe et al, 1997a, 1997b, 1998). MHV strain A59 from persistently infected murine cells exhibits an extended host range, being able to infect many cells lines of mammalian origin (Baric et al, 1999; Chen and Baric, 1996; Schickli et al, 1997, 1998). MHV spike deletion variants have been detected in the CNS (brain and spinal cord) from mice persistently infected with JHM, a highly neurovirulent MHV strain (Fleming et al, 1995). Mutants of MHV-A59, unable to induce hepatitis, may be selected by persistent infection of glial cells in vitro and hepatotropism revertants of these mutants may be selected from these mutants by multiple passage in the mouse liver (Gombold et al, 1993; Hingley et al, 1994, 1995; Leparc-Goffart et al, 1997). In addition, variants able to evade the CD8 cytotoxic lymphocytic (CTL), response (CTL escape mutants) have been identified in a murine model in which suckling mice are infected with the neurotropic MHV-JHM strain (Perlman and Pewe, 1998; Pewe et al, 1996, 1999), or mice that are immunized in an epitopespecific manner prior to infection with MHV-A59 (Chua et al, 2004).

\section{Coronavirus vaccines}

Currently, much effort is being done to develop vaccine strategies against SARS-CoV. The development 
of a vaccine against SARS needs to be based on the limited knowledge gained from studies on the immune response in SARS-infected patients, as well as in the coronavirus vaccine strategies that have been developed over the years. Most of the studies have focused on coronavirus infections on farm animals, but less is known on the immune response against human coronavirus HCoV-229E and HCoV-OC43.

In general, both humoral and cellular immune responses are required to protect against coronaviruses. T- and B-cell epitopes have been mapped to various coronavirus proteins. For example, CD4 T-cell epitopes have been identified in the spike (Xue and Perlman, 1997), M (Xue et al, 1995), and nucleocapsid (N) (van der Veen, 1996) proteins of MHV, and in the $\mathrm{N}$ protein of porcine TGEV (Anton et al, 1995) and avian coronaviruses (Boots et al, 1991). MHV spike glycoprotein contains all but one of the known virus specific $\mathrm{H}-2^{\mathrm{b}}$-restricted T-cell epitopes (Haring and Perlman, 2001). Various studies have demonstrated the importance of CD4 and CD8 T cells in host defense and viral clearance from the CNS during murine coronavirus infection (Bergmann et al, 1998, 2001; Chua et al, 2004; Marten et al, 2000, 2001; Perlman and $\mathrm{Wu}, 2001$; Wu et al, 2000a, 2000b, 2001). The B-cell response has been shown to be necessary to prevent recurrence of viral replication in the CNS after T cellmediated clearance in the early acute disease (Lin et al, 1999; Matthews et al, 2001). However, immune response contributes to pathogenesis in some coronavirus infections. For example, humoral immune response to FIPV may contribute to host pathology (Glansbeek et al, 2002), and T cells appear to be involved in the induction of CNS inflammation and demyelination observed in MHV-infected mice (Marten et al, 2001).

Most of the current knowledge on coronavirus vaccines has been generated by studies aimed at developing vaccine strategies for coronavirus of veterinary relevance, such as avian IBV and porcine TGEV. Live attenuated as well as killed coronavirus vaccines have been evaluated with some success. For IBV, live attenuated vaccine appears to be more effective than killed vaccine (Farsang et al, 2002). A killed canine coronavirus vaccine has been also developed (Pratelli et al, 2003), and a killed bovine coronavirus vaccine have been proved to be safe and effective (Takamura et al, 2002). Live attenuated coronavirus vaccines have been successfully combined with killed IBV (Farsang et al, 2002). A recent strategy to generate live attenuated coronavirus takes advantage of the deletion of "group specific genes" that are specific for each of the groups (de Haan et al, 2002a; Ortego et al, 2003).

Strikingly, epitope-driven approaches have been successfully attempted for IBV and MHV vaccine strategies. Chickens immunized with a DNA plas- mid encoding a CTL epitope from IBV were protected from acute viral infection (Wang and Khan, 2000; Wang et al, 2002). Plant viruses, such as a hybrid tobacco mosaic virus (TMV) carrying an epitope from the MHV spike protein, have been successfully used to develop immunity against murine coronavirus (MHV) (Koo et al, 1999). Intranasal or subcutaneous administration of this hybrid TMV induces parenteral and mucosal immunization, protecting from MHV challenge (Koo et al, 1999). Immunization against a CD8+ epitope of MHV using a recombinant Listeria monocytogenes vector or the adoptive transfer of epitope specific CD8+ T cells have been effective in reducing MHV-induced acute CNS disease and demyelination (Chua et al, 2004; MacNamara and Weiss, unpublished data). Antibodies elicited with a synthetic peptide comprising a B-cell epitope and a T-helper cell determinant can protect mice against an acute fetal MHV infection (Koolen et al, 1990).

Some recombinant constructs (recombinant vectored vaccines) have been shown to confer protection against several coronaviruses. A DNA vaccine containing the nucleoprotein of the porcine TGEV has been used to vaccinate against gastroenteritis, inducing both humoral and cellular immune response (Liu et al, 2001). A recombinant fowlpox containing the S1 gene of IBV has been produced and was shown to be relatively protective against IBV (Wang et al, 2002). A fowlpox virus expressing carboxyl-terminal nucleocapsid protein of IBV has also been developed (Yu et al, 2001).

It should be noticed that in some instances, coronavirus vaccines have been shown to induce enhancement of viral disease after vaccination by a mechanism that is not well understood, but is known to be related to the antibody response to spike. In particular, this has been reported for FIPV using different vaccination strategies (Olsen et al, 1993; Weiss and Scott, 1981).

The experience gained through all the vaccine strategies generated against some coronaviruses, such as IBV, TGEV, BCV, FIPV, and MHV should be considered for the development of a SARS vaccine.

\section{SARS update: Receptor, infectious clone}

Two major advances for the understanding of SARS pathogenesis, host tropism and vaccine development, have been already achieved. (i) A full-length infectious cDNA clone of SARS-CoV has been successfully assembled (Yount et al, 2003). (ii) The discovery of a receptor for SARS-CoV. Li et al (2003b) have identified a zinc metallopeptidase, angiotensinconverting enzyme 2 (ACE2) as a functional receptor for SARS-CoV. 


\section{References}

Adami C, Pooley J, Glomb J, Stecker E, Fazal F, Fleming JO, Baker SC (1995). Evolution of mouse hepatitis virus (MHV) during chronic infection: quasispecies nature of the persisting MHV RNA. Virology 209: 337-346.

Anton IM, Sune C, Meloen RH, Borras-Cuesta F, Enjuanes L (1995). A transmissible gastroenteritis coronavirus nucleoprotein epitope elicits $\mathrm{T}$ helper cells that collaborate in the in vitro antibody synthesis to the three major structural viral proteins. Virology 212: 746-751.

Ashraf H (2003). WHO declares Beijing to be free of SARS. Lancet 361: 2212.

Baric RS, Nelson GW, Fleming JO, Deans RJ, Keck JG, Casteel N, Stohlman SA (1988). Interactions between coronavirus nucleocapsid protein and viral RNAs: implications for viral transcription. J Virol 62: 4280-4287.

Baric RS, Sullivan E, Hensley L, Yount B, Chen W (1999). Persistent infection promotes cross-species transmissibility of mouse hepatitis virus. J Virol 73: 638-649.

Beauchemin N, Draber P, Dveksler G, Gold P, Gray-Owen S, Grunert F, Hammarstrom S, Holmes KV, Karlsson A, Kuroki M, Lin SH, Lucka L, Najjar SM, Neumaier M, Obrink B, Shively JE, Skubitz KM, Stanners CP, Thomas P, Thompson JA, Virji M, von Kleist S, Wagener C, Watt S, Zimmermann W (1999). Redefined nomenclature for members of the carcinoembryonic antigen family. Exp Cell Res 252: 243-249.

Bergmann CC, Dimacali E, Stohl S, Marten N, Lai MM, Stohlman SA (1998). Viral evolution and CTL epitope stability during JHMV infection in the central nervous system. Adv Exp Med Biol 440: 751-757.

Bergmann CC, Marten NW, Hinton DR, Parra B, Stohlman SA (2001). CD8 T cell mediated immunity to neurotropic MHV infection. Adv Exp Med Biol 494: 299-308.

Bonavia A, Arbour N, Yong VW, Talbot PJ (1997). Infection of primary cultures of human neural cells by human coronaviruses 229E and OC43. J Virol 71: 800-806.

Booth CM, Matukas LM, Tomlinson GA, Rachlis AR, Rose DB, Dwosh HA, Walmsley SL, Mazzulli T, Avendano M, Derkach P, Ephtimios IE, Kitai I, Mederski BD, Shadowitz SB, Gold WL, Hawryluck LA, Rea E, Chenkin JS, Cescon DW, Poutanen SM, Detsky AS (2003). Clinical features and short-term outcomes of 144 patients with SARS in the greater Toronto area. JAMA 289: 2801-2809.

Boots AM, Kusters JG, van Noort JM, Zwaagstra KA, Rijke E, van der Zeijst BA, Hensen EJ (1991). Localization of a T-cell epitope within the nucleocapsid protein of avian coronavirus. Immunology 74: 8-13.

Brian DA, Spaan WJM (1997). Recombination and coronavirus defective interfering RNAs. Semin Virol 8: 101111.

Buchmeier MJ, Lane TE (1999). Viral-induced neurodegenerative disease. Curr Opin Microbiol 2: 398-402.

Cavanagh D, Mawditt K, Welchman Dde B, Britton P, Gough RE (2002). Coronaviruses from pheasants (Phasianus colchicus) are genetically closely related to coronaviruses of domestic fowl (infectious bronchitis virus) and turkeys. Avian Pathol 31: 81-93.

Chen DS, Asanaka M, Chen FS, Shively JE, Lai MM (1997). Human carcinoembryonic antigen and biliary glycoprotein can serve as mouse hepatitis virus receptors. J Virol 71: 1688-1691.

Chen DS, Asanaka M, Yokomori K, Wang F, Hwang SB, Li HP, Lai MM (1995). A pregnancy-specific glycoprotein is expressed in the brain and serves as a receptor for mouse hepatitis virus. Proc Natl Acad Sci U S A 92: 12095-12099.

Chen W, Baric RS (1996). Molecular anatomy of mouse hepatitis virus persistence: coevolution of increased host cell resistance and virus virulence. J Virol 70: 39473960.

Chua MM, MacNamara K, San Mateo L, Shen H, Weiss SR (2004). Effects of an epitope specific CD8+ T cell response on murine coronavirus CNS disease: protection from virus replication and antigen spread and selection of epitope escape mutants. J Virol 78: 1150-1159.

Cinatl J, Morgenstern B, Bauer G, Chandra P, Rabenau H, Doerr HW (2003). Treatment of SARS with human interferons. Lancet 362: 293-294.

de Haan CA, Masters PS, Shen X, Weiss S, Rottier PJ (2002a). The group-specific murine coronavirus genes are not essential, but their deletion, by reverse genetics, is attenuating in the natural host. Virology 296: 177-189.

de Haan CA, van Genne L, Stoop JN, Volders H, Rottier PJ (2003). Coronaviruses as vectors: position dependence of foreign gene expression. J Virol 77: 11312-11323.

de Haan CA, Volders H, Koetzner CA, Masters PS, Rottier PJ (2002b). Coronaviruses maintain viability despite dramatic rearrangements of the strictly conserved genome organization. J Virol 76: 12491-12502.

Domingo E, Biefricher C, Holland JJ, Eigen M (2001). Quasispecies and RNA virus evolution: principles and consequences. Austin, TX: Landes Bioscience.

Domingo E, Holland JJ (1997). RNA virus mutations and fitness for survival. Annu Rev Microbiol 51: 151-178.

Domingo E, Menendez-Arias L, Holland JJ (1997). RNA virus fitness. Rev Med Virol 7: 87-96.

Donnelly CA, Ghani AC, Leung GM, Hedley AJ, Fraser C, Riley S, Abu-Raddad LJ, Ho LM, Thach TQ, Chau P, Chan KP, Lam TH, Tse LY, Tsang T, Liu SH, Kong JH, Lau EM, Ferguson NM, Anderson RM (2003). Epidemiological determinants of spread of causal agent of severe acute respiratory syndrome in Hong Kong. Lancet 361: 1761-1766.

Drake JW (1991). A constant rate of spontaneous mutation in DNA-based microbes. Proc Natl Acad Sci U $S$ A 88: 7160-7164.

Drosten C, Gunther S, Preiser W, van der Werf S, Brodt HR, Becker S, Rabenau H, Panning M, Kolesnikova L, Fouchier RA, Berger A, Burguiere AM, Cinatl J, Eickmann M, Escriou N, Grywna K, Kramme S, Manuguerra JC, Muller S, Rickerts V, Sturmer M, Vieth S, Klenk HD, Osterhaus AD, Schmitz H, Doerr HW (2003a). Identification of a novel coronavirus in patients with severe acute respiratory syndrome. N Engl J Med 348: 1967-1976.

Drosten C, Preiser W, Gunther S, Schmitz H, Doerr HW (2003b). Severe acute respiratory syndrome: identification of the etiological agent. Trends Mol Med 9: 325-327.

Dveksler GS, Dieffenbach CW, Cardellichio CB, McCuaig K, Pensiero MN, Jiang GS, Beauchemin N, Holmes KV (1993). Several members of the mouse carcinoembryonic antigen-related glycoprotein family are functional receptors for the coronavirus mouse hepatitis virus-A59. J Virol 67: 1-8.

Dveksler GS, Gagneten SE, Scanga CA, Cardellichio CB, Holmes KV (1996). Expression of the recombinant anchorless N-terminal domain of mouse hepatitis virus 
(MHV) receptor makes hamster of human cells susceptible to MHV infection. J Virol 70: 4142-4145.

Enjuanes LBD, Cavanagh D, Holmes K, Lai MMC, Laude H, Masters P, Rottier P, Sidell SG, Spaan WJM, Taguchi F, Talbot P (2000). Coronaviridae. In: Virus taxonomy classification and nomemclature of viruses. van Regenmortel MHV FC, Bishop DHL, Carsten EB, Estes MK, Lemon SM, McGeoch DJ, Maniloff J, Mayo MA, Pringle CR, Wickner RB (eds). San Diego: Academic Press, pp 835-849.

Escors D, Camafeita E, Ortego J, Laude H, Enjuanes L (2001). Organization of two transmissible gastroenteritis coronavirus membrane protein topologies within the virion and core. J Virol 75: 12228-12240.

Everard ML, Swarbrick A, Rigby AS, Milner AD (2001). The effect of ribavirin to treat previously healthy infants admitted with acute bronchiolitis on acute and chronic respiratory morbidity. Respir Med 95: 275-280.

Farsang A, Ros C, Renstrom LH, Baule C, Soos T, Belak S (2002). Molecular epizootiology of infectious bronchitis virus in Sweden indicating the involvement of a vaccine strain. Avian Pathol 31: 229-236.

Fischer F, Peng D, Hingley ST, Weiss SR, Masters PS (1997). The internal open reading frame within the nucleocapsid gene of mouse hepatitis virus encodes a structural protein that is not essential for viral replication. $J$ Virol 71: $996-1003$.

Fisman DN (2000). Hemophagocytic syndromes and infection. Emerg Infect Dis 6: 601-608.

Fleck F (2003). WHO says SARS outbreak is over, but fight should go on. BMJ 327: 70.

Fleming JO, Adami C, Pooley J, Glomb J, Stecker E, Fazal F, Baker SC (1995). Mutations associated with viral sequences isolated from mice persistently infected with MHV-JHM. Adv Exp Med Biol 380: 591-595.

Fleming JO, Houtman JJ, Alaca H, Hinze HC, McKenzie D, Aiken J, Bleasdale T, Baker S (1993). Persistence of viral RNA in the central nervous system of mice inoculated with MHV-4. Adv Exp Med Biol 342: 327-332.

Gallagher TM (2001). Murine coronavirus spike glycoprotein. Receptor binding and membrane fusion activities. Adv Exp Med Biol 494: 183-192.

Glansbeek HL, Haagmans BL, te Lintelo EG, Egberink HF, Duquesne V, Aubert A, Horzinek MC, Rottier PJ (2002). Adverse effects of feline IL-12 during DNA vaccination against feline infectious peritonitis virus. J Gen Virol 83: $1-10$.

Godfraind C, Langreth SG, Cardellichio CB, Knobler R, Coutelier JP, Dubois-Dalcq M, Holmes KV (1995). Tissue and cellular distribution of an adhesion molecule in the carcinoembryonic antigen family that serves as a receptor for mouse hepatitis virus. Lab Invest 73: 615627.

Gombold JL, Hingley ST, Weiss SR (1993). Fusion-defective mutants of mouse hepatitis virus A59 contain a mutation in the spike protein cleavage signal. J Virol 67: 45044512.

Gonzalez JM, Gomez-Puertas P, Cavanagh D, Gorbalenya AE, Enjuanes L (2003). A comparative sequence analysis to revise the current taxonomy of the family Coronaviridae. Arch Virol 148: 2207-2235.

Guan Y, Zheng BJ, He YQ, Liu XL, Zhuang ZX, Cheung CL, Luo SW, Li PH, Zhang LJ, Guan YJ, Butt KM, Wong KL, Chan KW, Lim W, Shortridge KF, Yuen KY, Peiris JS, Poon LL (2003). Isolation and characterization of viruses related to the SARS coronavirus from animals in southern China. Science 302: 276-278.

Haring J, Perlman S (2001). Mouse hepatitis virus. Curr Opin Microbiol 4: 462-466.

Herrewegh AA, Smeenk I, Horzinek MC, Rottier PJ, de Groot RJ (1998). Feline coronavirus type II strains 791683 and 79-1146 originate from a double recombination between feline coronavirus type I and canine coronavirus. J Virol 72: 4508-4514.

Hingley ST, Gombold JL, Lavi E, Weiss SR (1994). MHVA59 fusion mutants are attenuated and display altered hepatotropism. Virology 200: 1-10.

Hingley ST, Gombold JL, Lavi E, Weiss SR (1995). Hepatitis mutants of mouse hepatitis virus strain A59. Adv Exp Med Biol 380: 577-582.

Holland J, Domingo E (1998). Origin and evolution of viruses. Virus Genes 16: 13-21.

Holmes KV (1996). Coronaviridae: the viruses and their replication. In: Fields virology. Fields BN (ed). Philadelphia: Lippincott-Raven, pp. 1075-1103.

Holmes KV (2003). SARS-associated coronavirus. N Engl J Med 348: 1948-51.

Huelsenbeck JP, Ronquist F, Nielsen R, Bollback JP (2001). Bayesian inference of phylogeny and its impact on evolutionary biology. Science 294: 2310-2314.

Hung EC, Chim SS, Chan PK, Tong YK, Ng EK, Chiu RW, Leung CB, Sung JJ, Tam JS, Lo YM (2003). Detection of SARS coronavirus RNA in the cerebrospinal fluid of a patient with severe acute respiratory syndrome. Clin Chem 49: 2108-2109.

Jia W, Karaca K, Parrish CR, Naqi SA (1995). A novel variant of avian infectious bronchitis virus resulting from recombination among three different strains. Arch Virol 140: $259-271$.

Jonassen CM, Jonassen TO, Grinde B (1998). A common RNA motif in the $3^{\prime}$ end of the genomes of astroviruses, avian infectious bronchitis virus and an equine rhinovirus. J Gen Virol 79( Pt 4): 715-718.

Keck JG, Matsushima GK, Makino S, Fleming JO, Vannier DM, Stohlman SA, Lai MM (1988a). In vivo RNA-RNA recombination of coronavirus in mouse brain. J Virol 62: 1810-1813.

Keck JG, Soe LH, Makino S, Stohlman SA, Lai MM (1988b). RNA recombination of murine coronaviruses: recombination between fusion-positive mouse hepatitis virus A59 and fusion-negative mouse hepatitis virus 2.J Virol 62: 1989-1998.

Koo M, Bendahmane M, Lettieri GA, Paoletti AD, Lane TE, Fitchen JH, Buchmeier MJ, Beachy RN (1999). Protective immunity against murine hepatitis virus (MHV) induced by intranasal or subcutaneous administration of hybrids of tobacco mosaic virus that carries an MHV epitope. Proc Natl Acad Sci U S A 96: 7774-7779.

Koolen MJ, Borst MA, Horzinek MC, Spaan WJ (1990). Immunogenic peptide comprising a mouse hepatitis virus A59 B-cell epitope and an influenza virus T-cell epitope protects against lethal infection. J Virol 64: 6270-6273.

Koren G, King S, Knowles S, Phillips E (2003). Ribavirin in the treatment of SARS: a new trick for an old drug? Chin Med Assoc J 168: 1289-1292.

Kottier SA, Cavanagh D, Britton P (1995a). Experimental evidence of recombination in coronavirus infectious bronchitis virus. Virology 213: 569-580.

Kottier SA, Cavanagh D, Britton P (1995b). First experimental evidence of recombination in infectious bronchitis 
virus. Recombination in IBV. Adv Exp Med Biol 380: 551-556.

Ksiazek TG, Erdman D, Goldsmith CS, Zaki SR, Peret T, Emery S, Tong S, Urbani C, Comer JA, Lim W, Rollin PE, Dowell SF, Ling AE, Humphrey CD, Shieh WJ, Guarner J, Paddock CD, Rota P, Fields B, DeRisi J, Yang JY, Cox N, Hughes JM, LeDuc JW, Bellini WJ, Anderson LJ (2003). A novel coronavirus associated with severe acute respiratory syndrome. $N$ Engl J Med 348: 1953-1966.

Kunz J, Krause D, Kremer M, Dermietzel R (1994). The 140$\mathrm{kDa}$ protein of blood-brain barrier-associated pericytes is identical to aminopeptidase N. J Neurochem 62: 23752386.

La Monica N, Yokomori K, Lai MM (1992). Coronavirus mRNA synthesis: identification of novel transcription initiation signals which are differentially regulated by different leader sequences. Virology 188: 402-407.

Lai KN, Leung JC, Metz CN, Lai FM, Bucala R, Lan HY (2003). Role for macrophage migration inhibitory factor in acute respiratory distress syndrome. J Pathol 199: 496-508.

Lai MM (1992). RNA recombination in animal and plant viruses. Microbiol Rev 56: 61-79.

Lee N, Hui D, Wu A, Chan P, Cameron P, Joynt GM, Ahuja A, Yung MY, Leung CB, To KF, Lui SF, Szeto CC, Chung S, Sung JJ (2003). A major outbreak of severe acute respiratory syndrome in Hong Kong. $N$ Engl J Med 348: 1986-1994.

Leparc-Goffart I, Hingley ST, Chua MM, Jiang X, Lavi E, Weiss SR (1997). Altered pathogenesis of a mutant of the murine coronavirus MHV-A59 is associated with a Q159L amino acid substitution in the spike protein. Virology 239: 1-10.

Leung WK, To KF, Chan PK, Chan HL, Wu AK, Lee N, Yuen KY, Sung JJ (2003). Enteric involvement of severe acute respiratory syndrome-associated coronavirus infection. Gastroenterology 125: 1011-1017.

Li L, Wo J, Shao J, Zhu H, Wu N, Li M, Yao H, Hu M, Dennin $\mathrm{RH}$ (2003a). SARS-coronavirus replicates in mononuclear cells of peripheral blood (PBMCs) from SARS patients. J Clin Virol 28: 239-244.

Li W, Moore MJ, Vasilieva N, Sui J, Wong SK, Berne MA, Somasundaran M, Sullivan JL, Luzuriaga K, Greenough TC, Choe H, Farzan M (2003b). Angiotensin-converting enzyme 2 is a functional receptor for the SARS coronavirus. Nature 426: 450-454.

Lin MT, Hinton DR, Marten NW, Bergmann CC, Stohlman SA (1999). Antibody prevents virus reactivation within the central nervous system. J Immunol 162: 7358-7368.

Lipman MM, Cotler SJ (2003). Antiviral therapy for hepatitis C. Curr Treat Options Gastroenterology 6: 445-453.

Liu C, Kokuho T, Kubota T, Watanabe S, Inumaru S, Yokomizo Y, Onodera T (2001). DNA mediated immunization with encoding the nucleoprotein gene of porcine transmissible gastroenteritis virus. Virus Res 80: 75-82.

Look AT, Ashmun RA, Shapiro LH, Peiper SC (1989). Human myeloid plasma membrane glycoprotein CD13 (gp150) is identical to aminopeptidase N. J Clin Invest 83: 1299-1307.

Luytjes W, Bredenbeek PJ, Noten AF, Horzinek MC, Spaan WJ (1988). Sequence of mouse hepatitis virus A59 mRNA 2: indications for RNA recombination between coronaviruses and influenza $\mathrm{C}$ virus. Virology 166: 415422 .
Marra MA, Jones SJ, Astell CR, Holt RA, Brooks-Wilson A, Butterfield YS, Khattra J, Asano JK, Barber SA, Chan SY, Cloutier A, Coughlin SM, Freeman D, Girn N, Griffith OL, Leach SR, Mayo M, McDonald H, Montgomery SB, Pandoh PK, Petrescu AS, Robertson AG, Schein JE, Siddiqui A, Smailus DE, Stott JM, Yang GS, Plummer F, Andonov A, Artsob H, Bastien N, Bernard K, Booth TF, Bowness D, Czub M, Drebot M, Fernando L, Flick R, Garbutt M, Gray M, Grolla A, Jones S, Feldmann H, Meyers A, Kabani A, Li Y, Normand S, Stroher U, Tipples GA, Tyler S, Vogrig R, Ward D, Watson B, Brunham RC, Krajden M, Petric M, Skowronski DM, Upton C, Roper RL (2003). The genome sequence of the SARS-associated coronavirus. Science 300: 1399-1404.

Marten NW, Stohlman SA, Atkinson RD, Hinton DR, Fleming JO, Bergmann CC (2000). Contributions of CD8+ T cells and viral spread to demyelinating disease. $J$ Immunol 164: 4080-4088.

Marten NW, Stohlman SA, Bergmann CC (2001). MHV infection of the CNS: mechanisms of immune-mediated control. Viral Immunol 14: 1-18.

Martin J, Navas S, Quiroga JA, Pardo M, Carreno V (1998). Effects of the ribavirin-interferon alpha combination on cultured peripheral blood mononuclear cells from chronic hepatitis C patients. Cytokine 10: 635-644.

Martina BE, Haagmans BL, Kuiken T, Fouchier RA, Rimmelzwaan GF, Van Amerongen G, Peiris JS, Lim W, Osterhaus AD (2003). Virology: SARS virus infection of cats and ferrets. Nature 425: 915.

Matthews AE, Weiss SR, Shlomchik MJ, Hannum LG, Gombold JL, Paterson Y (2001). Antibody is required for clearance of infectious murine hepatitis virus A59 from the central nervous system, but not the liver. J Immunol 167: 5254-5263.

Myint SH (1994). Human coronaviruses-a brief review. Rev Med Virol 4: 35-46.

Navas-Martín S, Weiss SR (2003). SARS: lessons learned from other coronaviruses. J Viral Immunol In press.

Nedellec P, Dveksler GS, Daniels E, Turbide C, Chow B, Basile AA, Holmes KV, Beauchemin N (1994). Bgp2, a new member of the carcinoembryonic antigen-related gene family, encodes an alternative receptor for mouse hepatitis viruses. J Virol 68: 4525-4537.

Nicholls JM, Poon LL, Lee KC, Ng WF, Lai ST, Leung CY, Chu CM, Hui PK, Mak KL, Lim W, Yan KW, Chan KH, Tsang NC, Guan Y, Yuen KY, Peiris JS (2003). Lung pathology of fatal severe acute respiratory syndrome. Lancet 361: 1773-1778.

Nie QH, Luo XD, Zhang JZ, Su Q (2003). Current status of severe acute respiratory syndrome in China. World J Gastroenterol 9: 1635-1645.

Olsen CW, Corapi WV, Jacobson RH, Simkins RA, Saif LJ, Scott FW (1993). Identification of antigenic sites mediating antibody-dependent enhancement of feline infectious peritonitis virus infectivity. J Gen Virol 74(Pt 4): 745-749.

Ortego J, Sola I, Almazan F, Ceriani JE, Riquelme C, Balasch M, Plana J, Enjuanes L (2003). Transmissible gastroenteritis coronavirus gene 7 is not essential but influences in vivo virus replication and virulence. Virology 308: $13-22$.

Parry J (2003). WHO investigates China's fall in SARS cases. BMJ 326: 1285.

Peiris JS, Chu CM, Cheng VC, Chan KS, Hung IF, Poon LL, Law KI, Tang BS, Hon TY, Chan CS, Chan KH, 
Ng JS, Zheng BJ, Ng WL, Lai RW, Guan Y, Yuen KY (2003a). Clinical progression and viral load in a community outbreak of coronavirus-associated SARS pneumonia: a prospective study. Lancet 361: 1767-1772.

Peiris JS, Lai ST, Poon LL, Guan Y, Yam LY, Lim W, Nicholls J, Yee WK, Yan WW, Cheung MT, Cheng VC, Chan KH, Tsang DN, Yung RW, Ng TK, Yuen KY (2003b). Coronavirus as a possible cause of severe acute respiratory syndrome. Lancet 361: 1319-1325.

Perlman S, Pewe L (1998). Role of CTL mutants in demyelination induced by mouse hepatitis virus, strain JHM. Adv Exp Med Biol 440: 515-519.

Perlman S, Wu GF (2001). Selection of and evasion from cytotoxic T cell responses in the central nervous system. Adv Virus Res 56: 219-242.

Pewe L, Heard SB, Bergmann C, Dailey MO, Perlman S (1999). Selection of CTL escape mutants in mice infected with a neurotropic coronavirus: quantitative estimate of TCR diversity in the infected central nervous system. J Immunol 163: 6106-6113.

Pewe L, Wu GF, Barnett EM, Castro RF, Perlman S (1996). Cytotoxic T cell-resistant variants are selected in a virusinduced demyelinating disease. Immunity 5: 253-262.

Poutanen SM, Low DE, Henry B, Finkelstein S, Rose D, Green K, Tellier R, Draker R, Adachi D, Ayers M, Chan AK, Skowronski DM, Salit I, Simor AE, Slutsky AS, Doyle PW, Krajden M, Petric M, Brunham RC, McGeer AJ (2003). Identification of severe acute respiratory syndrome in Canada. N Engl J Med 348: 1995-2005.

Pratelli A, Tinelli A, Decaro N, Cirone F, Elia G, Roperto S, Tempesta M, Buonavoglia C (2003). Efficacy of an inactivated canine coronavirus vaccine in pups. New Microbiol 26: 151-155.

Prentice E, Denison MR (2001). The cell biology of coronavirus infection. Adv Exp Med Biol 494: 609-614.

Reilley B, Van Herp M, Sermand D, Dentico N (2003). SARS and Carlo Urbani. N Engl J Med 348: 1951-1952.

Rest JS, Mindell DP (2003). SARS associated coronavirus has a recombinant polymerase and coronaviruses have a history of host-shifting. Infect Genet Evol 3: 219-225.

Robitaille J, Izzi L, Daniels E, Zelus B, Holmes KV, Beauchemin N (1999). Comparison of expression patterns and cell adhesion properties of the mouse biliary glycoproteins Bbgp1 and Bbgp2. Eur J Biochem 264: 534-544.

Rota PA, Oberste MS, Monroe SS, Nix WA, Campagnoli R, Icenogle JP, Penaranda S, Bankamp B, Maher K, Chen MH, Tong S, Tamin A, Lowe L, Frace M, DeRisi JL, Chen Q, Wang D, Erdman DD, Peret TC, Burns C, Ksiazek TG, Rollin PE, Sanchez A, Liffick S, Holloway B, Limor J, McCaustland K, Olsen-Rasmussen M, Fouchier R, Gunther S, Osterhaus AD, Drosten C, Pallansch MA, Anderson LJ, Bellini WJ (2003). Characterization of a novel coronavirus associated with severe acute respiratory syndrome. Science 300: 1394-1399.

Rowe CL, Baker SC, Nathan MJ, Fleming JO (1997a). Evolution of mouse hepatitis virus: detection and characterization of spike deletion variants during persistent infection. J Virol 71: 2959-2969.

Rowe CL, Baker SC, Nathan MJ, Sgro JY, Palmenberg AC, Fleming JO (1998). Quasispecies development by high frequency RNA recombination during MHV persistence. Adv Exp Med Biol 440: 759-765.

Rowe CL, Fleming JO, Nathan MJ, Sgro JY, Palmenberg AC, Baker SC (1997b). Generation of coronavirus spike deletion variants by high-frequency recombination at regions of predicted RNA secondary structure. J Virol 71: 6183-6190.

Schickli JH, Wentworth DE, Zelus BD, Holmes KV, Sawicki SG (1998). Selection in persistently infected murine cells of an MHV-A59 variant with extended host range. Adv Exp Med Biol 440: 735-741.

Schickli JH, Zelus BD, Wentworth DE, Sawicki SG, Holmes KV (1997). The murine coronavirus mouse hepatitis virus strain A59 from persistently infected murine cells exhibits an extended host range. J Virol 71: 9499-9507.

Siddell SG (1995). The Coronaviridae. New York: Plenum Press.

Snijder EJ, Bredenbeek PJ, Dobbe JC, Thiel V, Ziebuhr J, Poon LL, Guan Y, Rozanov M, Spaan WJ, Gorbalenya $A E$ (2003). Unique and conserved features of genome and proteome of SARS-coronavirus, an early split-off from the coronavirus group 2 lineage. J Mol Biol 331: 991-1004.

Steinhauer DA, Domingo E, Holland JJ (1992). Lack of evidence for proofreading mechanisms associated with an RNA virus polymerase. Gene 122: 281-288.

Takamura K, Matsumoto Y, Shimizu Y (2002). field study of bovine coronavirus vaccine enriched with hemagglutinating antigen for winter dysentery in diary cows. Can $J$ Vet Res 66: 278-281.

Talbot PJ (1995). Implication of viruses in multiple sclerosis. Med Sci 11: 837-843.

To KF, Chan PK, Chan KF, Lee WK, Lam WY, Wong KF, Tang NL, Tsang DN, Sung RY, Buckley TA, Tam JS, Cheng AF (2001). Pathology of fatal human infection associated with avian influenza A H5N1 virus. J Med Virol 63: 242246.

Tsui PT, Kwok ML, Yuen H, Lai ST (2003). Severe acute respiratory syndrome: clinical outcome and prognostic correlates. Emerg Infect Dis 9: 1064-1069.

van der Veen RC (1996). Immunogenicity of JHM virus proteins: characterization of a CD4+ T cell epitope on nucleocapsid protein which induces different T-helper cell subsets. Virology 225: 339-346.

Vennema H, Godeke GJ, Rossen JW, Voorhout WF, Horzinek MC, Opstelten DJ, Rottier PJ (1996). Nucleocapsidindependent assembly of coronavirus-like particles by co-expression of viral envelope protein genes. $E M B O J$ 15: 2020-2028.

Wang X, Khan MI (2000). Molecular characterization of an infectious bronchitis virus strain isolated from an outbreak in vaccinated layers. Avian Dis 44: 1000-1006.

Wang X, Schnitzlein WM, Tripathy DN, Girshick T, Khan MI (2002). Construction and immunogenicity studies of recombinant fowl poxvirus containing the S1 gene of Massachusetts 41 strain of infectious bronchitis virus. Avian Dis 46: 831-838.

Weiss R, Scott FW (1981). Antibody-mediated enhancement of disease in feline infectious peritonitis: comparisons with dengue hemorragic fever. Comp Immunol Microbiol Infect Dis 4: 175-189.

Wentworth DE, Holmes KV (2001a). Addition of a single glycosylation site to hAPN blocks human coronavirus229E receptor activity. Adv Exp Med Biol 494: 199-204.

Wentworth DE, Holmes KV (2001b). Molecular determinants of species specificity in the coronavirus receptor aminopeptidase N (CD13): influence of $N$-linked glycosylation. J Virol 75: 9741-9752.

World Health Organization (WHO) (2003). Severe acute respiratory syndrome (SARS): multi-country outbreak. 
Wu GF, Dandekar AA, Pewe L, Perlman S (2000a). CD4 and CD8 T cells have redundant but not identical roles in virus induced demyelination. J Immunol 165: 22782286.

Wu GF, Dandekar AA, Pewe L, Perlman S (2001). The role of CD4 and CD8 T cells in MHV-JHM-induced demyelination. Adv Exp Med Biol 494: 341-347.

Wu GF, Pewe L, Perlman S (2000b). Coronavirusinduced demyelination occurs in the absence of inducible nitric oxide synthase. $J$ Virol 74: 76837686.

Wu HY, Guy JS, Yoo D, Vlasak R, Urbach E, Brian DA (2003). Common RNA replication signals exist among group 2 coronaviruses: evidence for in vivo recombination between animal and human coronavirus molecules. Virology 315: 174-183.

Xu X, Liu Y, Weiss S, Arnold E, Sarafianos SG, Ding J (2003). Molecular model of SARS coronavirus polymerase: implications for biochemical functions sand drug design. Nucleic Acids Res 31: 7117-7130.

Xue S, Jaszewski A, Perlman S (1995). Identification of a $\mathrm{CD} 4+\mathrm{T}$ cell epitope within the $\mathrm{M}$ protein of a neurotropic coronavirus. Virology 208: 173-179.
Xue S, Perlman S (1997). Antigen specificity of CD4 T cell response in the central nervous system of mice infected with mouse hepatitis virus. Virology 238: 68-78.

Yeager CL, Ashmun RA, Williams RK, Cardellichio CB, Shapiro LH, Look AT, Holmes KV (1992). Human aminopeptidase $\mathrm{N}$ is a receptor for human coronavirus 229E. Nature 357: 420-422.

Yount B, Curtis KM, Fritz EA, Hensley LE, Jahrling PB, Prentice E, Denison MR, Geisbert TW, Baric RS (2003). Reverse genetics with a full-length infectious cDNA of severe acute respiratory syndrome coronavirus. Proc Natl Acad Sci U S A 100: 12995-13000.

Yu L, Liu W, Schnitzlein WM, Tripathy DN, Kwang J (2001). Avian Dis 45: 340-348.

Yu X, Bi W, Weiss SR, Leibowitz JL (1994). Mouse hepatitis virus gene $5 \mathrm{~b}$ protein is a new virion envelope protein. Virology 202: 1018-1023.

Zhong NS, Zheng BJ, Li YM, Poon, Xie ZH, Chan KH, Li PH, Tan SY, Chang Q, Xie JP, Liu XQ, Xu J, Li DX, Yuen KY, Peiris, Guan Y (2003). Epidemiology and cause of severe acute respiratory syndrome (SARS) in Guangdong, People's Republic of China, in February, 2003. Lancet 362: 1353-1358. 